\title{
The Role of Knowledge Sharing and Innovation on Employee Performance
}

\author{
Fauziyah $^{1, *}$ Zenida Wella Rahayunus ${ }^{1}$
}

\author{
${ }^{1}$ Department of Management, Faculty of Economics and Business, Universitas Muhammadiyah Yogyakarta, Indonesia \\ *Corresponding author. Email: Fauziyah@umy.ac.id
}

\begin{abstract}
The impact of knowledge sharing on employee performance has attracted considerable research attention over the last decade. However, there is limited research done in Indonesia, especially in higher education under the auspices of the Muhammadiyah organization. Nowadays, there is an awareness of the importance of knowledge sharing in creating a competitive advantage. Moreover, supported by individual innovation capabilities, knowledge sharing can be more effective. This study analyzed the role of individual innovation capabilities as a mediation between knowledge sharing and employee performance. One hundred eighty-seven questionnaires were distributed to permanent lecturers at Muhammadiyah universities in Yogyakarta. The results showed that knowledge sharing positively and significantly affected individual innovation capabilities. Both individual innovation capabilities and knowledge sharing had a positive and significant impact on employee performance. This research has proven that individual innovation capabilities play an essential role in mediation between knowledge sharing and employee performance.
\end{abstract}

\section{Keywords: Knowledge Sharing, Individual Innovation Capabilities, Employee Performance,} Muhammadiyah Universities.

\section{INTRODUCTION}

Knowledge is an intangible asset in an organization that should maximize its utilization. Currently, knowledge management began to become the focus of attention among practitioners and academics. The organization has realized that in order to compete in the fast-evolving market, there is a need to include competence and knowledge offered to the customers [1]. In this "knowledge era," only organizations that can manage their knowledge optimally will survive in a competitive environment. Knowledge is the key for an organization to have a sustainable competitive advantage. Organizational learning also enables companies to build capabilities and intellectual capital, which can provide the firm with the ability to manage intangible resources for a sustainable competitive advantage [2].

One of the activities that play a role in knowledge management is knowledge sharing. Better knowledge sharing allows us to disseminate, implement, and develop existing knowledge. If knowledge is not shared systematically, it will be detrimental to the organization because knowledge is only inherent in the mind. Sharing knowledge can also stimulate an individual to think creatively, effectively, efficiently, and innovatively. The company hopes that this ability can generate new knowledge that is useful for them.

The main focus of innovation is creating new ideas so that they can implement products or processes. The main goal of innovation is to provide effectiveness and efficiency levels that can improve employee performance and ultimately impact organizational performance.

This phenomenon does not only apply to profitoriented organizations but also non-profit organizations, such as colleges. In this case, Yogyakarta is a student city based on data on the website of the Ministry of Research, Technology, and Higher Education. It has 137 colleges that are still actively operating. This high number makes each organization (college) compete healthily to survive in the increasingly fierce competition, including Muhammadiyah Universities in Yogyakarta. Muhammadiyah is a community organization with a vast network in education, health, and da'wah. The latest data uncovered that Muhammadiyah has 162 universities, consisting of 57 universities, 80 colleges, five academies, seven institutes, three polytechnics, and eight Aisyiyah Universities. To provide quality services for their students, these organizations must create value from innovation and superior employee performance. 
However, there is limited research on knowledge sharing in Muhammadiyah organizations.

Based on the phenomena described above, it is necessary to research the effect of knowledge sharing and individuals' ability to innovate on employees' performance to be carried out at Muhammadiyah Colleges in Yogyakarta. This research is hoped to be useful as an input to develop knowledge for researchers, readers, and the organizations themselves.

\section{LITERATURE REVIEW AND HYPOTHESES}

\section{Knowledge Sharing}

Knowledge sharing is one of the methods in the knowledge management cycle where individuals share or exchange their knowledge to create a new one later [3]. Knowledge sharing is the primary process of the knowledge management section. It provides broad learning opportunities for all organization members to increase their abilities independently [4]. Therefore, effective knowledge sharing is needed so that knowledge management is carried out successfully in an organization or company. Knowledge sharing is a process to communicate explicit or tacit knowledge to other individuals [5].

\section{Individual Innovation Capability}

Innovation is the application of their new ideas into products, processes, and other aspects of the company's activities. Innovation focuses on the process of turning ideas into values [6]. The individual innovation capability is the ability of each individual to apply new ideas he/she has in a product or process [7]. Increased ability to innovate can help individuals overcome problems in the work so that the quality and quantity of work can be better. The high capacity to innovate can support the emergence of initiatives to produce more effective and efficient work methods.

\section{Employee Performance}

Performance is a general term employed for some or all actions or activities of an organization in a period. Employee performance indicates the employee's financial or non-financial outcome that directly links with the performance of the organization and its success [8].

According to Sedarmayanti [9], performance is the work result of each individual to achieve organizational goals. It allows the employee to demonstrate the work results concretely and measurable (compared with predetermined standards).

\section{Knowledge Sharing and Individual Innovation Capabilities}

By sharing knowledge with other individuals, the expertise will increase. These activities are closely related to improving individuals' ability to innovate through the knowledge they have. Capability or capacity in innovation is the ability to adapt and integrate all expertise, functional competencies, and available resources. Explicit knowledge sharing and tacit knowledge sharing affect innovation speed and quality significantly [10].

Therefore, the following hypothesis was proposed:

H1: Knowledge sharing is positively related to individual innovation capability.

\section{Individual Innovation Capability and Employee Performance}

The increased ability to innovate will help individuals overcome problems in work so that the quality and quantity of work can be better than before. The wellinnovated ability will help individuals take the initiative to produce ideas so the work process more effective and efficient. The ability to innovate is indicated by always trying new ideas, trying new operating methods, and product innovation. All will improve employee performance [11].

Thus, the second hypothesis was proposed:

$\mathrm{H} 2$ : Individual innovation capability is positively related to employee performance.

\section{Knowledge Sharing and Employee Performance}

Knowledge sharing activities that include sharing experiences and knowledge possessed will help individuals solve problems encountered in work based on real experience. Likewise, individuals will get more knowledge to improve their work processes' effectiveness and efficiency from sharing this knowledge. It can directly enhance individual performance. That way, increased knowledge sharing activities will affect individual performance improvement [12].

Therefore, the following hypothesis was proposed:

H3: Knowledge sharing is positively related to employee performance.

\section{Knowledge Sharing on Employee Performance through Individual Innovation Capabilities}

Knowledge sharing carried out by individuals one to another can increase their knowledge, which can bring up new ideas in the work process. It means the better implementation of knowledge sharing, the higher the improvement and innovation capability. The high individual innovation will later affect employees' 
performance, which will indirectly affect the company's performance improvement [13].

Thus, the fourth hypothesis was proposed:

H4: Knowledge sharing is positively related to employee performance through individual innovation capability.

\section{RESEARCH MODEL}

Figure 1 describes the research model.

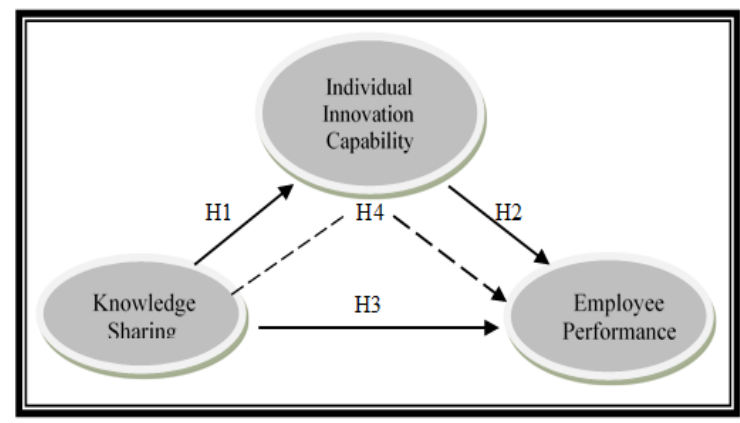

Figure 1 The Research Model

\section{METHODOLOGY}

\section{Sampling and Data Collection}

A quantitative research method was adopted to achieve the research aims. The population included employees (lectures) of Muhammadiyah and Aisyiyah Universities in Yogyakarta: Universitas Muhammadiyah Yogyakarta, Universitas Ahmad Dahlan, and Universitas Aisyiyah Yogyakarta. A sample of $15 \%$ was taken from the total number of lecturers in the three universities. A total of 187 questionnaires was collected and suitable for analysis. This study used a purposive sampling technique, with the criteria: (1) Lecturers, who were permanent employees at the universities; (2) The minimum working period was one year.

\section{Measurement}

Knowledge sharing was measured with eight items based on two indicators: tacit knowledge and explicit knowledge, adopted from Hoof and Ridder [3]. Eight items from three indicators were employed to measure individual innovation capability, adopted from Aulawi, et al. [14], including personal character, behavior, and innovation results. Meanwhile, employee performance used five indicators adopted from Bangun [15], comprising the number of jobs, quality of work, timeliness, attendance, and ability to work together. It consisted of nine items.

Besides, Structural Equation Modeling (SEM) was utilized to analyze data. It is a good tool to analyze behavioral research.

\section{RESULTS AND ANALYSIS}

\section{Validity and Reliability}

A validity test is a test conducted to determine the extent to which the measuring instrument used in the study is appropriate and related to the variable. The valid items are indicated by the Factor Loading $>0.5$ and declared invalid if the Factor Loading value $<0.5$ [16] In this study, the research instrument consisted of 25 lists of statements, representing each of the three variables with total respondents of 187 . The Factor Loading value of all question items showed a number $>0.5$, so the validity test results indicated that all question indicators were declared valid.

Further, the reliability test was used to determine the instrument's consistency from time to time. The reliable items are indicated by the value of Construct Reliability (CR). CR equal to or higher than 0.7 means that the instrument is reliable [17]. Variance Extracted (VE) was also employed, with criteria $>0.5$.

The following are the reliability test results:

Table 1. Reliability

\begin{tabular}{|l|c|c|}
\hline Variables & Construct Reliability & Variance Extracted \\
\hline Knowledge Sharing & 0.91 & 0.56 \\
\hline Individual Innovation Capability & 0.93 & 0.63 \\
\hline Employee Performance & 0.94 & 0.62 \\
\hline Variables & Construct Reliability & 0.56 \\
\hline Knowledge Sharing & 0.91 & 0.63 \\
\hline Individual Innovation Capability & 0.93 & 0.94 \\
\hline Employee Performance & 0.92 & 0.62 \\
\hline
\end{tabular}

Source: Data processed, 2019 
In this study, CR values indicated the number $>0.7$ and VE $>0.5$ so that all the instruments were reliable and could be used for the next step.

\section{The Evaluation of SEM Assumptions}

The SEM assumption test was conducted, consisting of the data normality test and outlier test. The normality test used the z-value of the skewness and kurtosis of data distribution. It was found that the data distribution was normal so that it met the normality assumption. Likewise, the evaluation of multivariate outliers was seen through the output of Mahalanobis Distance, and the results revealed no outlier data discovered.

\section{The Goodness of Fit Model}

Assessing the goodness of fit is the main goal in SEM to find out how far the hypothesized model is "Fit" or according to the existing data sample.

The following table is the goodness of fit results in this study:

Table 2. The Goodness of Fit Test Results

\begin{tabular}{|l|l|l|l|}
\hline The goodness of fit index & Cut-off value & This Model & Results \\
\hline Chi-square & Less than 311,467 & 343,461 & Marginal \\
\hline Significant probability & $(\mathrm{df}=272, \mathrm{p}=0.05)$ & 0,002 & Farginal \\
\hline RMSEA & $\geq 0.05$ & 0,038 & Marginal \\
\hline GFI & $\leq 0.08$ & 0,874 & Fit \\
\hline AGFI & $\geq 0.90$ & 0,849 & Fit \\
\hline CMIN/DF & $\geq 0.80$ & 1,263 & Fit \\
\hline TLI & $\leq 2.00$ & 0,976 & Fit \\
\hline CFI & $\geq 0.90$ & 0,978 & \\
\hline
\end{tabular}

Source: Data processed, 2019

Table 2 shows that five of the eight criteria were eligible. Regarding the parsimony principle proposed by Arbuckle and Wothke [18], if one or two criteria have been met (fit), the overall model can be accepted. Thus, this study's model was accepted.

\section{Hypothesis Test Results}

Table 3. Hypotheses Testing Results
One way to see the hypothesis testing results is the output of standardized regression weight. Regression weight is a tool to test a relationship between exogenous variables and endogenous variables. Ghozali [19] states that the hypothesis can be accepted if the result of the probability value is smaller than 0.05 , and the $\mathrm{CR}$ is higher than 2.00. Here are the results of the $\mathrm{H} 1, \mathrm{H} 2$, and H3 tests:

\begin{tabular}{|l|r|l|l|l|l|l|}
\hline & & & $\begin{array}{l}\text { Standardized } \\
\text { Estimate }\end{array}$ & SE & CR & P \\
\hline $\begin{array}{l}\text { Individual Innovation } \\
\text { Capability }\end{array}$ & $\leftarrow$ & Knowledge Sharing & 0.632 & 0.085 & 7.418 & 0,000 \\
\hline Employee Performance & $\leftarrow$ & $\begin{array}{l}\text { Individual } \\
\text { Innovation } \\
\text { Capability }\end{array}$ & 0.762 & 0.075 & 10.097 & 0,000 \\
\hline Employee Performance & $\leftarrow$ & Knowledge Sharing & 0.142 & 0.052 & 2.722 & 0,006 \\
\hline
\end{tabular}

Source: Data processed, 2019

The table presents that all three hypotheses were supported according to the criteria used. Meanwhile, to test hypothesis 4 , the values of standardized direct and indirect effects were compared. Table IV displays the standardized direct and indirect effect outputs.

The results revealed the direct effect value of $0.146<$ the indirect effect value of 0.495 . It denoted that the indirect effect's value was higher than the direct effect value so that the individual innovation capability could mediate the effect of knowledge sharing on employee performance. In other words, better knowledge sharing will create good individual innovation capabilities and impact improving employee performance. This result supported hypothesis 4. 
Table 4. Standardized Direct and Indirect Effect

\begin{tabular}{|l|c|c|c|c|}
\hline & Standardized Direct Effect & \multicolumn{2}{c|}{ Standardized Indirect Effect } \\
\hline $\begin{array}{l}\text { Individual Innovation } \\
\text { Capability }\end{array}$ & 0.598 & 0.000 & 0.000 & 0.000 \\
\hline $\begin{array}{l}\text { Employee } \\
\text { Performance }\end{array}$ & 0.146 & 0.828 & 0.495 & 0.000 \\
\hline
\end{tabular}

\section{DISCUSSION}

The better sharing of knowledge between employees will encourage the creation of good cooperation between them. The knowledge sharing activities carried out among these employees will produce creative ideas to enhance innovation, process, and product innovation. Examples of knowledge sharing activities carried out among lecturers are sharing expertise, new information, and new references owned by individuals. This study's results are similar to the research by Zoohori et al. [10], [20], [14], [21], [22], [11].

Sharing good knowledge is one of the significant factors in increasing individual innovation capability possessed by lecturers at the Muhammadiyah Universities at Yogyakarta. Individuals who have an excellent ability to innovate will have better performance. The better the individuals' innovation capability, the better the individuals will do their work, improving their performance as employees. The employees who manage their resources by developing new ideas can achieve their performance. In practice, lecturers at Muhammadiyah Higher Education can innovate, indicated by their ability to create useful new ideas for the university. These results support previous research by Azadehdel et al. [3], [11], [22].

Sharing knowledge between individuals in an organization will produce new ideas that are more creative and innovative to complete their tasks. The better the knowledge shared by each individual, the more effective and efficient individual will be in completing work to improve the individual performance as an employee. The results align with previous studies conducted by Wening et al. [12], [23], [24], 22], which states that there is a positive and significant influence between knowledge sharing on employee performance.

Knowledge sharing between individuals can increase their knowledge. Furthermore, this knowledge can be used to generate new ideas and innovations in the work process. Increasing this individual innovation capability can also affect employee performance, directly affecting the company's performance improvement.

Therefore, it could be concluded that there was an indirect effect between knowledge sharing variables on employee performance through innovation capabilities.
These results are in agreement with the previous research carried out by Azadehdel et al. [13], [23], [25], [22].

\section{CONCLUSION}

Sharing good knowledge is one of the significant factors in increasing individual innovation capability possessed by lecturers at the Muhammadiyah Universities at Yogyakarta. Knowledge sharing between individuals can increase their knowledge. This knowledge can be used to generate new ideas and innovations in the work process. Increasing this individual innovation capability can also affect employee performance, directly affecting the company's performance improvement. Therefore, it could be concluded that there was an indirect effect between knowledge sharing variables on employee performance through innovation capabilities.

\section{RESEARCH LIMITATION}

In conducting this research, several limitations were encountered, as follows:

1. Self-report was employed for employee performance variables. It allows for bias.

2. This study also only used the perspective of several theories that explain the influence between related variables. Many other theories can provide different views on this research topic.

\section{RECOMMENDATION AND FUTURE RESEARCH}

Based on the discussion and conclusions above, the suggestions are as follows:

1. For universities, these results can be an input to assist its employees, which in this case are lecturers, to increase the knowledge sharing activities.

2. For lecturers, these results are expected to encourage the enthusiasm to increase knowledge sharing activities to improve individual innovation capabilities and individual employee performance. Furthermore, it can directly improve higher education performance. 
3. For further research, it needs to use interviewing techniques to get more prosperous and more indepth results.

\section{ACKNOWLEDGMENTS}

We want to thank Universitas Muhammadiyah Yogyakarta, especially the Management Study Program so that this research could be carried out.

\section{REFERENCES}

[1] E. Orr, M. Persson. Performance Indicators for Measuring Performance of Activities in Knowledge Management Projects, Department of Informatics, University of Gothenburg, 2003.

[2] N. Chauhan, N. Bontis. Organizational learning via groupware: a path to discovery or disaster? International Journal of Technology Management, 2004, vol. 27(6-7), 591-610. DOI: 10.1504/IJTM.2004.004904

[3] B. Hooff, J. Ridder. Knowledge saharing in context: The influence of organizational communication climate and CMC use on knowledge sharing, J. Knowledge Management, 2004, vol. 8, 117-130. https://doi.org/10.1108/13673270410567675

[4] P.L. Tobing. Knowledge management: konsep, arsitektur dan implementasi, $1^{\text {st }}$ edition. Graha Ilmu, Yogyakarta, 2007.

[5] I. Becerra-Fernandez, A.J. González, R. Sabherwal. Knowledge Management: Challenges, Solutions, and Technologies, Pearson Prentice Hall, New Jersey, 2004.

[6] M. Roger. The Definition and Measurement of Innovation, Working paper No 10/98, Melbourne Institute of Applied Economic and Social Research: The University of Melbourne, 1998.

[7] J. Wallin, A. Larsson, O. Isaksson, T. Larsson. Measuring Innovation Capability-Assessing Collaborative Performance in Product-Service System Innovation. In Functional Thinking for Value Creation. Springer Berlin Heidelberg, 2011, pp. 207212.

[8] J. Anitha. Determinants of employee engagement and their impact on employee performance. International Journal of Productivity and Performance Management, 2014, vol. 63 (3), pp.308-323.

[9] Sedarmayanti. Manajemen Sumber Daya Manusia, Reformasi Birokrasi, dan Manajemen Pegawai Negeri Sipil. Bandung. PT. Refika Aditama, 2016.

[10] M. Zoohori, S. Mohseni, B.A. Samadi. The Relationship Between Knowledge Sharing and Innovation in Electronic Industry of Iran, Journal of Small Business and Entrepreneurship, 2013.

[11] M. Asegaff, Wasitowati. Knowledge Sharing Sebagai Sumber Inovasi dan Keunggulan Bersaing Pada Usaha Mikro Kecil dan Menengah (UMKM) Sektor Batik, Jurnal.unissula.ac.id., 2015.
[12] N. Wening, T. Haryono, M. Harsono. (2016). Relationship Between Knowledge Sharing to Individual Performance: The Role of Organizational Culture and Relationship Quality As Moderator in Family Business, Journal of Research in Business Management, vol. 4(1), 67-78.

[13] M.R. Azadehdel, F. Farahbod, M.A. Jamshidinejad. The Relationship between Knowledge Sharing, Innovation, and Performance, Interdisciplinary Journal of Contemporary Research In Business, 2013, vol. 5, No 5, 408 - 412.

[14] H. Aulawi, R. Govindaraju, K. Suryadi, I. Sudirman. Hubungan Knowledge Sharing Behaviour dan Individual Innovation Capability, Jurnal Teknik Industri, 2009, vol. 11(2), 174-187.

[15] W. Bangun. Wilson. Manajemen Sumber Daya Manusia. Erlangga, Jakarta, 2012.

[16] I. Ghozali. Konsep dan Aplikasi dengan Program AMOS 22.0, Badan Penerbit UNDIP, Semarang, 2014.

[17] I. Ghozali, Aplikasi Analisis Multivariate dengan Program IBM SPSS 19, Badan Penerbit UNDIP, Semarang, 2011.

[18] J.L. Arbuckle, W. Wothke. Amos 4.0 user's guide, SmallWaters Corporation, USA, 1999.

[19] I. Ghozali, I. Model Persamaan Struktural: Konsep dan Aplikasi dengan Program AMOS 24, Badan Penerbit UNDIP, Semarang, 2016.

[20] Ologbo, A. C., Md Nor, K., \& Okyere-Kwakye, E. (2015). The Influence of Knowledge Sharing on Employee Innovation Capabilities. International Journal of Human Resource Studies, 5(3), 102.

[21] D.W.P. Ranto. Pengaruh Knowledge Sharing terhadap Kemampuan Inovasi Usaha Kecil Menengah (UKM) di Yogyakarta dengan Absorptive Capacity sebagai Variabel Intervening, Jurnal Siasat Bisnis, 2015, vol 19 No. 2. https://doi.org/10.20885/jsb.vol19.iss2.art4

[22] D.B. Aristanto. Pengaruh Knowledge Sharing terhadap Individual Innovation Capability dan Kinerja Karyawan (Studi pada PT. PLN (PERSERO) Unit Induk Pembangunan Sulawesi Bagian Utara), Jurnal EMBA, 2017, vol 5(2), 1539-1545. https://doi.org/10.35794/emba.v5i2.16224

[23] A. Aulia. Pengaruh Budaya Organisasi Terhadap Kinerja Karyawan Melalui Knowledge Sharing Sebagai Variabel Intervening (Studi Pada PT. Pelabuhan Indonesia III), Jurnal Ilmu Manajemen, 2016, vol. 4(3), 1-15.

[24] A.P. Mangkunegara. Manajemen Sumber Daya Manusia Perusahaan, PT. Remaja Rosdakarya, Bandung, 2014

[25] N.S. Saputro, Y. Manyowa. Pengaruh Knowledge Sharing terhadap Individual Innovation Capability dan Kinerja Karyawan (Studi pada Karyawan Rumah Opa Kitchen and Lounge), Jurnal Administrasi Bisnis, 2018, vol. 55(3). 